\title{
KOMBINASI TEKNOLOGI ELEKTROKOAGULASI DAN FOTOKATALISIS DALAM MEREDUKSI LIMBAH BERBAHAYA DAN BERACUN Cr (VI)
}

\author{
(TECHNOLOGY COMBINATION OF ELECTROCOAGULATION AND \\ PHOTOCATALYTIC FOR REDUCING HAZARDOUS DAN TOXIC WASTE Cr (VI))
}

\author{
Bumiarto Nugroho Jati dan Silvie Ardhanie Aviandharie \\ Balai Besar Kimia dan Kemasan, Kementerian Perindustrian \\ Jl. Balai Kimia No.1 Pekayon, Pasar Rebo, Jakarta Timur \\ E-mail : bumiarto_1108@yahoo.com
}

Received : 7 September 2015; revised : 14 September 2015; accepted : 21 September 2015

\begin{abstract}
ABSTRAK
Teknologi elektrokoagulasi dan fotokatalisis telah diterapkan dalam mereduksi limbah $\mathrm{Cr}(\mathrm{VI})$ yang sangat berbahaya dan beracun yang berasal dari limbah $\mathrm{Cr}(\mathrm{VI})$ sintetik. Proses elektrokoagulasi diawali dengan mencari tegangan proses yang optimal untuk elektroda alumunium, besi, dan kombinasi keduanya dengan variasi tegangan $1,5 \mathrm{~V} ; 3 \mathrm{~V} ; 4,5 \mathrm{~V} ; 6 \mathrm{~V} ; 9 \mathrm{~V}$ dan $12 \mathrm{~V}$. Elektroda alumunium dengan tegangan $6 \mathrm{~V}$ dipilih untuk diuji selama 6 jam dan disampling setiap jam. Hasil penelitian reduksi yang optimal yaitu sebesar $65,2 \%$ diperoleh dengan waktu proses selama 3 jam. Selanjutnya penelitian dilanjutkan dengan proses fotokatalisis untuk limbah yang telah diolah dengan elektrokoagulasi dengan menggunakan variasi komposit $\mathrm{TiO}_{2}-\mathrm{karbon}$ aktif dan $\mathrm{TiO}_{2}$-zeolit selama 6 jam dan analisa disampling setiap jam. Proses fotokatalisis paling optimal dapat mereduksi $\mathrm{Cr}(\mathrm{VI})$ sebesar 98,8\% dengan menggunakan komposit $\mathrm{TiO}_{2}$-karbon aktif selama 5 jam menjadi $0,1 \mathrm{mg} / \mathrm{L}$. Konsentrasi akhir limbah $\mathrm{Cr}(\mathrm{VI})$ tersebut sudah aman jika dibuang ke lingkungan karena sudah memenuhi baku mutu limbah cair yang dipersyaratakan sesuai dengan Kep-51/MENLH/10/1995. Pada proses akhir juga tidak dihasilkan sludge yang berbahaya bagi lingkungan.
\end{abstract}

Kata kunci : Elektrokoagulasi, Fotokatalisis, $\mathrm{Cr}(\mathrm{VI})$

\begin{abstract}
Electrocoagulation and photocatalytic technology has been applied to reduction the $\mathrm{Cr}$ (VI) which is very dangerous and toxic waste originating from $\mathrm{Cr}(\mathrm{VI})$ synthetic. Electrocoagulation process begins with finding the optimal voltage to the electrode process aluminum, iron, and a combination of both with variations in voltage of $1.5 \mathrm{~V} ; 3 \mathrm{~V} ; 4.5 \mathrm{~V} ; 6 \mathrm{~V} ; 9 \mathrm{~V}$ and $12 \mathrm{~V}$. The aluminum electrodes with a voltage of $6 \mathrm{~V}$ was chosen to be tested for 6 hours and sampled every hour. Degradation optimal research results in the amount of $65.2 \%$ was obtained with the process time for 3 hours. Furthermore, the study continued with the photocatalytic process for the waste that has been processed with electrocoagulation by using a variation of composite $\mathrm{TiO}_{2}$-activated carbon and $\mathrm{TiO}_{2}$ zeolite for 6 hours and analysis of sampled every hour. The most optimal photocatalytic process can reduce $\mathrm{Cr}(\mathrm{VI})$ amounted to $98.8 \%$ with the use of composite $\mathrm{TiO}_{2}$-activated carbon for 5 hours to $0.1 \mathrm{mg} / \mathrm{L}$. Waste final concentration of $\mathrm{Cr}(\mathrm{VI})$ has been safe if released into the environment because it meets the effluent standards accordance with Kep-51/MENLH/10/1995. At the end of the process is also not generated sludge that is harmful to the environment.
\end{abstract}

Keywords: Electrocoagulation, Photocatalytic, $\mathrm{Cr}(\mathrm{VI})$

\section{PENDAHULUAN}

Limbah krom memiliki potensi yang besar sebagai bahan pencemar karena krom merupakan salah satu komponen logam berat yang sangat berbahaya dan beracun. Krom terdapat di alam dalam dua bentuk oksida yaitu
$\mathrm{Cr}$ (VI) atau kromium heksavalen dan $\mathrm{Cr}$ (III) atau kromium trivalen. $\mathrm{Cr}(\mathrm{VI})$ mudah larut dalam air dan membentuk oksanion divalen. Tingkat toksisitas $\mathrm{Cr}(\mathrm{VI})$ sangat tinggi sehingga bersifat racun terhadap semua organisme, sementara itu 
toksisitas $\mathrm{Cr}$ (III) jauh lebih rendah bila dibanding Cr (VI) yaitu 1/100 kali nya (Slamet et al. 2005). Limbah $\mathrm{Cr}$ (VI) banyak dihasilkan dari limbah industri cat, pelapisan logam dan penyamakan kulit.

Selama ini teknologi yang digunakan dalam mereduksi logam berat adalah teknologi flotasi dan koagulasi dengan penambahan alum (alumunium sulfat), feri klorida $\left(\mathrm{FeCl}_{3}\right)$, fero sulfat $\left(\mathrm{FeSO}_{4}\right)$ (Buttler 2011). Penggunaan teknologi tersebut banyak menimbulkan kendala karena menggunakan bahan kimia yang banyak dan tidak ramah lingkungan. Penggunaan teknologi elektrokoagulasi dapat meminimalkan penggunaan bahan kimia selama proses berlangsung sehingga secara ekonomi maupun lingkungan akan lebih menguntungkan apabila diterapkan dalam skala industri.

Proses elektrokoagulasi merupakan gabungan dari proses elektrokimia, proses flokulasi dan koagulasi (Susetyaningsih et al. 2008). Elektrokoagulasi merupakan metode pengolahan air secara elektrokimia dimana pada anoda terjadi pelepasan koagulan aktif berupa ion logam ke dalam larutan. Sedangkan pada katoda terjadi reaksi elektrolisis berupa pelepasan gas hidrogen (Kashefi et al 2014). Pembentukan ion logam sebagai koagulan memerlukan perbedaan potensial antar elektroda. Perbedaan potensial ini diperlukan untuk menimbulkan reaksi elektrokimia pada masing-masing elektroda. Reaksi yang terjadi di dalam elektroda adalah reduksi dan oksidasi. Reaksi reduksi dan oksidasi ditandai oleh adanya transfer elektron dari zat yang dioksidasi (reduktor) menjadi zat yang direduksi (oksidator) (Trapsilasiwi et al. 2012). Ektrokoagulasi merupakan suatu proses koagulasi kontinyu dengan menggunakan arus listrik searah melalui peristiwa elektrokimia dimana elektrodanya logam. Dalam proses ini akan terjadi proses reaksi reduksi dimana logam-logam akan direduksi dan diendapkan di katoda.

Elektroda dalam proses elektrokoagulasi merupakan salah satu alat untuk menghantarkan arus listrik ke dalam larutan agar larutan tersebut terjadi reaksi kimia. Reaksi yang terjadi pada proses elektrokoagulasi yaitu proses reduksi dan oksidasi sebagai akibat adanya arus listrik searah (DC). Pada reaksi ini terjadi pergerakan dari ion-ion positif (kation) yang bergerak pada katoda yang bermuatan negatif sedangkan ion-ion negatif bergerak menuju anoda yang bermuatan positif.

Proses elektrokoagulasi terbentuk melalui pelarutan logam dari anoda yang kemudian berinteraksi secara simultan dengan ion hidroksi dan gas hidrogen yang dihasilkan dari katoda.
Kation bermuatan tinggi mendestabilisasi beberapa partikel koloid dengan membentuk polivalen polihidroksi komplek. Senyawa komplek ini mempunyai sisi yang mudah diadsorbsi membentuk gumpalan dengan polutan. Pelepasan gas hidrogen akan membantu pencampuran dan pembentukan flok. Pada penelitian ini, proses elektrokoagulasi akan dikombinasi dengan proses fotokatalisis titanium dioksida $\left(\mathrm{TiO}_{2}\right)$ di mana $\mathrm{TiO}_{2}$ merupakan bahan semikonduktor. Aktivitas fotokatalisisnya mampu mereduksi bahan beracun $\mathrm{Cr}$ (VI) (Naimah et al. 2012; Setiawati et al. 2006) dan total krom (Jati et al. 2012). Proses fotokatalisis diawali dengan energi foton yang bersumber dari cahaya UV yang menyinari katalis $\mathrm{TiO}_{2}$ akan menyebabkan elektron $\left(e^{-}\right)$pada pita valensi mengalami fotoeksitasi ke pita konduksi dan meninggalkan lubang positif $\left(\right.$ hole $^{+}$. disingkat sebagai $h^{+}$) pada pita valensi. $\mathrm{TiO}_{2}$ dengan struktur kristal anastase merupakan semikonduktor dengan band-gap energy sebesar 3.2 eV (Wang 2004).

Untuk meningkatkan kinerja dari proses fotokatalis, $\mathrm{TiO}_{2}$ dapat dikompositkan dengan karbon aktif dan zeolit. Karbon aktif merupakan salah satu penyangga dengan daya adsorpsi cukup baik karena memiliki volume pori yang luar biasa besar sehingga memiliki luas permukaan yang besar untuk tempat terjadinya reaksi kimia (Slamet et al. 2006). Zeolit banyak digunakan sebagai adsorben yang secara ekonomis dapat digunakan sebagai bahan penyerap logam berbahaya dan senyawa B3 cair. Faktor penting berkaitan dengan penggunaan zeolit untuk menyerap logam berbahaya dalam limbah industri adalah kemampuan zeolit sebagai penukar ion (Kismolo 2012). Tujuan dari penelitian ini adalah untuk memaksimalkan proses reduksi limbah $\mathrm{Cr}(\mathrm{VI})$ dengan mengkombinasikan antara teknologi elektrokoagulasi dengan teknologi fotokatalisis.

Kombinasi elektrokoagulasi dan fotokatalis dilakukan sebagai upaya untuk meminimalisir penggunaan bahan kimia dalam pengolahan limbah cair, diperoleh hasil yang maksimal dalam mengolah limbah cair serta energi yang dibutuhkan dapat lebih efisien dan tidak menimbulkan sludge (Boroski et al. 2009 dan Zhang et al. 2013).

\section{BAHAN DAN METODE}

\section{Bahan}

Bahan yang digunakan dalam penelitian ini antara lain akuades, kalium dikromat $\left(\mathrm{K}_{2} \mathrm{Cr}_{2} \mathrm{O}_{7}\right), \mathrm{TiO}_{2} \mathrm{P}-25$ Degussa, karbon aktif, zeolit aktif, TEOS (Tetra Etil Orto Silikat), gelas 
piala, plat anoda dan katoda yang terbuat dari alumunium $(\mathrm{Al})$ dan besi $(\mathrm{Fe})$. Sedangkan alat yang digunakan adalah adaptor Nagoya power $5 \mathrm{~A}$ dengan tegangan yang bervariasi, reaktor fotokatalis, lampu UV, alat sonikasi Chromtech, oven Memmert, tanur Yamato, pengaduk magnet Cimarec, dan spektrofotometer ultraviolet-visible (UV-VIS) Shimadzu.

\section{Metode}

Metode percobaan diawali dengan pembuatan limbah sintetis $\mathrm{Cr}$ (VI) dilanjutkan dengan proses degradasi $\mathrm{Cr}$ (VI) dengan teknologi elektrokoagulasi dan fotokatalisis. Limbah sintetis $\mathrm{Cr}(\mathrm{VI})$ dibuat dari larutan kalium dikromat $\left(\mathrm{K}_{2} \mathrm{Cr}_{2} \mathrm{O}_{7}\right)$ hingga diperoleh konsentrasi $\mathrm{Cr}(\mathrm{VI})$ sebesar $25 \mathrm{mg} / \mathrm{L}$.

Proses elektrokoagulasi diawali dengan mencari tegangan proses yang paling optimal untuk elektroda alumunium, besi, serta kombinasi alumunium-besi selama dua jam waktu reaksi ke dalam $300 \mathrm{~mL}$ limbah sintetis $\mathrm{Cr}$ (VI) dan telah terhubung dengan adaptor yang telah teraliri listrik. Proses elektrokoagulasi dilakukan dengan melakukan variasi terhadap tegangan proses yaitu $1,5 \mathrm{~V} ; 3 \mathrm{~V} ; 4,5 \mathrm{~V} ; 6 \mathrm{~V}$; 7,5 V; $9 \mathrm{~V}$ dan $12 \mathrm{~V}$. Setelah diperoleh elektroda yang optimal mereduksi $\mathrm{Cr}(\mathrm{VI})$, selanjutnya dilakukan pengolahan limbah $\mathrm{Cr}$ (VI) dengan variasi waktu proses 1 jam, 2 jam, 3 jam, 4 jam, 5 jam, dan 6 jam. Proses yang optimal dipilih untuk selanjutnya diproses menggunakan teknologi fotokatalisis. Proses ini diawali dengan pembuatan keramik pada cetakan yang telah disiapkan lalu dikeringkan dalam suhu ruang selama 24 jam kemudian di oven pada suhu $100{ }^{\circ} \mathrm{C}$.

Proses pembuatan komposit $\mathrm{TiO}_{2-}$ adsorben dibuat dengan cara mencampur $4,5 \mathrm{~g}$ serbuk $\mathrm{TiO}_{2}$ dengan $100 \mathrm{~mL}$ akuades lalu disonifikasi selama 30 menit. Setelah itu ditambahkan larutan TEOS 0,5 mL dan disonifikasi kembali selama 5 menit. Setelah itu ditambahkan 0,5 g adsorben (karbon aktif atau zeolite aktif) dan disonifikasi kembali selama 30 menit.

Lapisan tipis dibuat dengan mengoleskan larutan sol ke atas permukaan keramik dengan tujuan agar terjadi ikatan yang komposit lebih kuat, lalu dikeringkan pada suhu ruangan dilanjutkan pengeringan di dalam oven selama satu jam pada suhu $100{ }^{\circ} \mathrm{C}$. Media yang telah terlapisi selanjutnya dikalsinasi di dalam tanur suhu $350{ }^{\circ} \mathrm{C}$ selama 2 jam. Pelapisan diulang sebanyak 2 kali sampai terbentuk lapisan yang merata dan seragam pada media.
Setelah proses elekrokoagulasi selanjutnya dilakukan proses fotokatalisis secara batch dalam reaktor tertutup yang dilengkapi lampu UV blacklight blue merk Sankyo Denki 10 Watt dengan panjang gelombang $352 \mathrm{~nm}$ dan pengaduk. Proses ini menggunakan variasi jenis komposit $\mathrm{TiO}_{2}$-karbon aktif maupun $\mathrm{TiO}_{2}$-zeolit dengan waktu proses 1 jam, 2 jam, 3 jam, 4 jam, dan 5 jam. Masing-masing perlakuan dianalisa penurunan $\mathrm{Cr}(\mathrm{VI})$ dengan menggunakan Spektrofotometer UV-VIS Shimadzu.

\section{HASIL DAN PEMBAHASAN}

Proses elektrokoagulasi merupakan proses yang melibatkan 2 reaksi yaitu reaksi reduksi dan reaksi oksidasi (redoks), selama proses berlangsung terjadi transfer elektron pada elektroda dimana reduktor berperan sebagai pemberi elektron dan oksidator sebagai penerima elektron. Perpindahan elektron tersebut berpengaruh terhadap pembentukan flok-flok yang berfungsi untuk mengikat logam $\mathrm{Cr}(\mathrm{VI})$. Kemampuan dalam melakukan reaksi redoks dapat dilihat dari nilai potensial reduksi $\left(E^{\circ}\right)$ masing-masing logam yang digunakan sebagai elektroda. Alumunium memiliki nilai potensial redoks sebesar $-1,662$ sedangkan nila potensial redoks dari besi adalah $-0,444$. Selain faktor nilai potensial reduksi $\left(E^{\circ}\right)$, faktor lain yang berpengaruh dalam proses perpindahan elektron adalah energi ionisasi yang merupakan energi minimum yang dibutuhkan untuk melepaskan elektron dari suatu ikatan, energi ionisasi ini bergantung kepada nomor atom dan jari-jari atom.

Pada saat proses elektrokoagulasi berlangsung, terjadi aliran listrik yang melewati anoda dan katoda akan menyebabkan berpindahnya elektron dari katoda menuju anoda. Hal ini sesuai dengan hukum Faraday 1 yang berbunyi massa zat yang timbul pada elektroda yang disebabkan karena proses elektrolisis berbanding lurus dengan jumlah listrik yang mengalir melalui larutan, sedangkan hukum Ohm menyatakan bahwa kuat arus (I) berbanding terbalik dengan tahanan dan berbanding lurus dengan tegangan. Pada percobaan yang dilakukan, peralatan yang digunakan berupa adaptor yang memiki kuat arus 5A seperti pada Gambar 1. Setelah aliran listrik mengalir maka akan terbentuk molekul $\mathrm{Al}(\mathrm{OH})_{3}$ yang berikatan dengan logam $\mathrm{Cr}(\mathrm{VI})$ sehingga terbentuk flok-flok yang dapat mengendap. Semakin lama aliran listrik berlangsung maka akan semakin banyak flok yang terbetuk mengikat logam $\mathrm{Cr}$ (VI). 


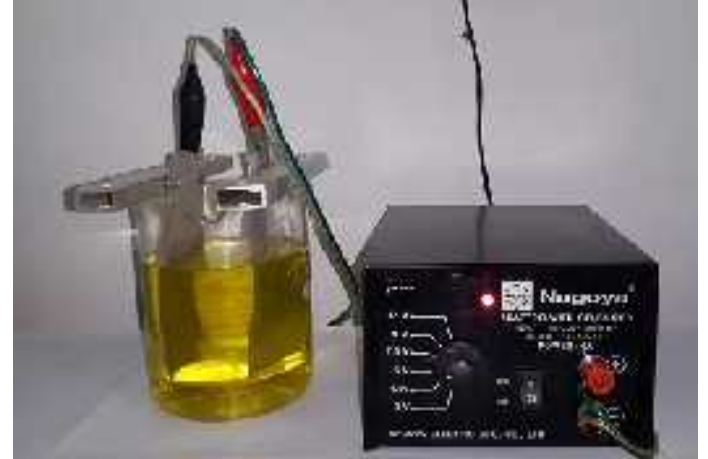

Gambar 1. Rangkaian alat proses elektro-koagulasi

Pada Gambar 2 tampak adanya penurunan logam $\mathrm{Cr}(\mathrm{VI})$ setelah proses elektrokoagulasi dengan elektroda alumunium selama 2 jam dengan variasi tegangan $1,5 \mathrm{~V} ; 3$ V; 4,5 V; 6 V; 7,5 V; 9 V dan 12 V. Hasil optimal terjadi pada tegangan $6 \mathrm{~V}$ yang mampu mereduksi limbah $\mathrm{Cr}(\mathrm{VI})$ dengan konsentrasi awal $25 \mathrm{mg} / \mathrm{L}$ menjadi $9,3 \mathrm{mg} / \mathrm{L}$ atau tereduksi sebesar $62,8 \%$. Dari grafik dapat dilihat setelah melalui proses dengan tegangan $6 \mathrm{~V}$, maka grafik akan naik pada saat tegangan $7,5 \mathrm{~V}$ dan cenderung konstan. Hal ini mengindikasikan bahwa terlalu tinggi tegangan proses dapat menyebabkan proses perpindahan elektron yang terlalu cepat sehingga proses pembentukan flok tidak optimal.

Di awal proses elektrokoagulasi terjadi gelembung-gelembung yang disebabkan karena terbentuknya gas hidrogen yang terbentuk dari pelepasan ion elektron dari katoda menuju anoda sebagai akibat dari proses elektrokoagulasi menyebabkan kotoran-kotoran yang terbentuk akan mengendap pada saat proses elektrokoagulasi berlangsung, proses ini berfungsi mengendapkan flok-flok yang terbentuk (Siringo-Ringo 2013) sedangkan pada anoda ion $\mathrm{Al}^{3+}$ akan teroksidasi menjadi $\mathrm{Al}(\mathrm{OH})_{3}$ yang berfungsi sebagai koagulan dan pada katoda terjadi reduksi terhadap kation (Hari et al. 2010).

Pada proses elektrokoagulasi menggunakan elektroda besi selama 2 jam dengan variasi tegangan $1,5 \mathrm{~V} ; 3 \mathrm{~V} ; 4,5 \mathrm{~V} ; 6 \mathrm{~V}$; 7,5 V; $9 \mathrm{~V}$ dan $12 \mathrm{~V}$ diperoleh hasil seperti pada Gambar 2. Hasil optimal ditunjukkan oleh tegangan $4,5 \mathrm{~V}$ yang mampu mereduksi limbah $\mathrm{Cr}(\mathrm{VI})$ dari $25 \mathrm{mg} / \mathrm{L}$ menjadi $14,2 \mathrm{mg} / \mathrm{L}$ atau tereduksi sebesar $43,2 \%$ selama 2 jam. Proses pembentukan flok diawali dengan pelepasan elektron oleh katoda sehingga terjadi koagulan $\mathrm{Fe}(\mathrm{OH})_{2}$ yang akan mengikat logam $\mathrm{Cr}(\mathrm{VI})$.

Molekul yang terbentuk pada proses elektrokoagulasi $\quad \mathrm{Al}(\mathrm{OH})_{3}$ dan $\mathrm{Fe}(\mathrm{OH})_{2}$ merupakan koagulan yang berfungsi mengendapkan molekul $\mathrm{Cr}(\mathrm{VI})$ yang berada pada cairan elektrolit penghantar listrik. Proses koagulasi merupakan proses dimana zat melayang dengan ukuran sangat kecil dan koloid digabungkan dengan membentuk flokflok. Koagulan yang terjadi pada proses elektrokoagulasi akan menyebabkan pembentukan presipitat akan cepat dimana partikel-partikel yang tersuspensi dalam air mempunyai muatan listrik pada permukaannya, muatan ini disebebkan karena adsorpsi ion-ion $\left(\mathrm{OH}^{-}\right)$dari dalam air. Ion-ion tersebut mengelilingi rapat permukaan partikel dan menarik ion-ion yang bermuatan dari dalam larutan, gaya tarik menarik antar partikel yaitu gaya van der waals mengakibatkan koloid-koloid bergabung membentuk flok-flok (Susanto 2008).

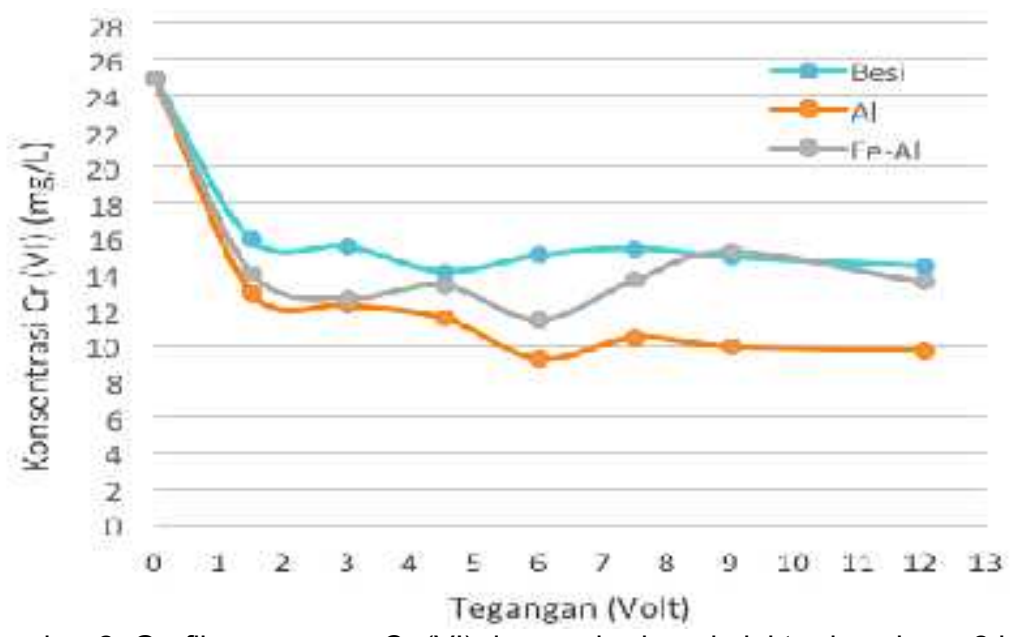

Gambar 2. Grafik penurunan $\mathrm{Cr}(\mathrm{VI})$ dengan berbagai elektroda selama 2 jam 
Pada proses elektrokoagulasi terjadi proses koagulasi, reduksi dan oksidasi, dimana pada permukaan anoda terjadi oksidasi yang akan menghasilkan ion $\mathrm{Fe}^{2+}$ yang akan bereaksi dengan ion hidroksi $\left(\mathrm{OH}^{-}\right)$akan membentuk koagulan sehingga dalam proses yang terjadi tegangan listrik sangat berpengaruh terhadap pembentukan kaogulan $\mathrm{Fe}(\mathrm{OH})_{2}$ dimana koagulan tersebut akan mengikat logam $\mathrm{Cr}$ (VI). Menurut Harmami et al. (2014) dan Zongo et al. (2012), reaksi yang terjadi pada elektroda besi sebagai berikut:

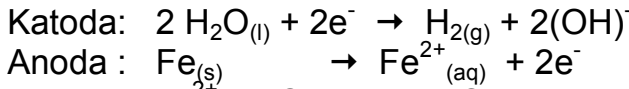$$
\mathrm{Fe}^{2+}+2 \mathrm{OH}^{-} \rightarrow \mathrm{Fe}(\mathrm{OH})_{2(\mathrm{~s})}
$$

Setelah dilakukan percobaan dengan elektroda alumunium dan besi, selanjutnya dilakukan pengolahan limbah $\mathrm{Cr}$ (VI) dengan kombinasi elektroda alumunium sebagai katoda dan besi sebagai anoda selama 2 jam dengan variasi tegangan $1,5 \mathrm{~V} ; 3 \mathrm{~V} ; 4,5 \mathrm{~V} ; 6 \mathrm{~V} ; 7,5 \mathrm{~V}$; $9 \mathrm{~V}$ dan $12 \mathrm{~V}$. Penggabungan elektroda ini dimaksudkan untuk melihat performa dari gabungan elektroda alumunium dan besi. Pada Gambar 2 tampak penurunan limbah $\mathrm{Cr}$ (VI). Hasil optimal ditunjukkan oleh tegangan $6 \mathrm{~V}$ yang mampu mereduksi limbah menjadi $11,5 \mathrm{mg} / \mathrm{L}$ atau tereduksi sebesar $54 \%$. Proses ektrokoagulasi diawali dengan mengalirkan listrik dengan melakukan variasi tegangan yaitu $1,5 \mathrm{~V} ; 3 \mathrm{~V} ; 4,5 \mathrm{~V} ; 6 \mathrm{~V} ; 7,5 \mathrm{~V} ; 9 \mathrm{~V}$ dan $12 \mathrm{~V}$ selama 2 jam. Pada saat listrik mengalir, maka akan terjadi pelepasan electron yang berfungsi sebagai pembentukan flok-flok yang akan berguna untuk mengikat logam $\mathrm{Cr}(\mathrm{VI})$.

Berdasarkan percobaan selama 2 jam, proses penurunan $\mathrm{Cr}(\mathrm{VI})$ yang optimal adalah dengan menggunakan elektroda alumunium dengan tegangan proses sebesar $6 \mathrm{~V}$. Hal ini dapat terjadi karena pada deret volta, posisi aluminium terletak di sebelah kiri besi. Pada deret volta, unsur logam dengan potensial elektroda lebih negatif ditempatkan sebelah kiri sedangkan unsur dengan potensial elektroda yang lebih positif ditempatkan sebelah kanan. Semakin ke kiri kedudukan suatu logam dalam deret tersebut maka logam akan semakin mudah melepas elektron dan merupakan reduktor yang semakin kuat (semakin mudah mengalami oksidasi).

Oleh karena itu pada tahap selanjutnya proses elektrokoagulasi dilanjutkan menggunakan elektroda alumunium dengan tegangan $6 \mathrm{~V}$ dengan melakukan variasi waktu proses 1 jam, 2 jam, 3 jam, 4 jam, 5 jam dan 6 jam. Setiap jam dilakukan sampling terhadap limbah yang diolah dan hasil percobaan dapat dilihat pada Gambar 3. Dari gambar tersebut tampak bahwa setelah 1 jam konsentrasi logam $\mathrm{Cr}$ (VI) mengalami penurunan dan hasil optimal ditunjukkan waktu 3 jam yang mampu mereduksi limbah $\mathrm{Cr}(\mathrm{VI})$ hingga $8,7 \mathrm{mg} / \mathrm{L}$ atau tereduksi sebesar $65,2 \%$.

Konsentrasi limbah $\mathrm{Cr}$ (VI) dari hasil proses elektrokoagulasi masih jauh dari $0,1 \mathrm{mg} / \mathrm{L}$ sebagai batas maksimal baku mutu limbah $\mathrm{Cr}$ (VI) yang dipersyaratkan (Kep-51/ MENLH/10/ 1995). Oleh karena itu harus dilakukan proses lanjutan yatu proses fotokatalisis yang diawali dengan membuat lapisan $\mathrm{TiO}_{2}$-karbon aktif dan $\mathrm{TiO}_{2}$-zeolit pada permukaan keramik yang dapat dilihat pada Gambar 4 dan Gambar 5. Keramik yang digunakan untuk media menempelnya komposit $\mathrm{TiO}_{2-}$ karbon aktif dan $\mathrm{TiO}_{2}$-zeolit merupakan keramik khusus sehingga komposit tidak mudah lepas dan dapat bertahan lama apabila digunakan terus menerus.

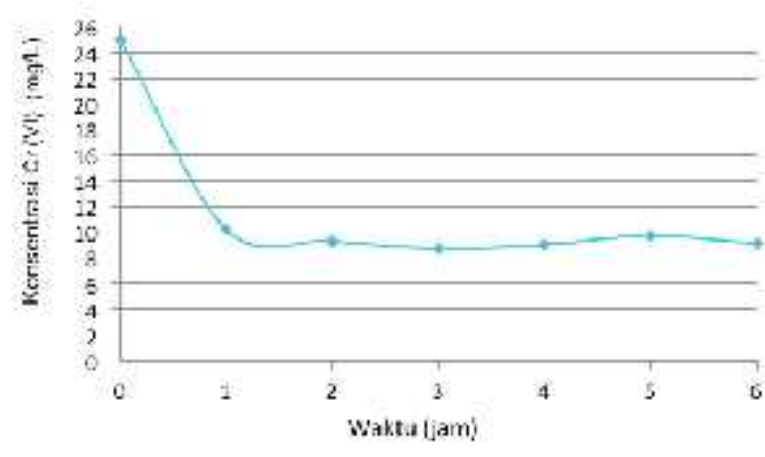

Gambar 3. Grafik penurunan $\mathrm{Cr}$ (VI) dengan menggunakan elektroda alumunium dengan variasi waktu proses

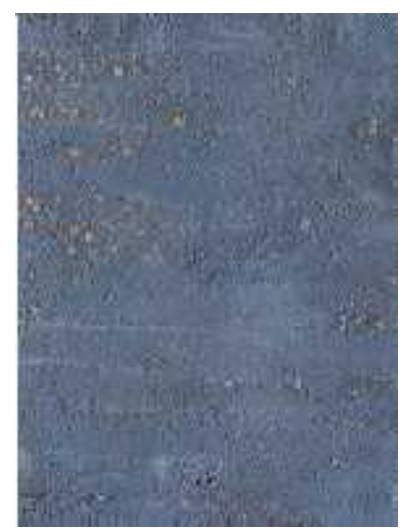

Gambar 4. Lapisan $\mathrm{TiO}_{2}$-karbon aktif pada permukaan keramik 


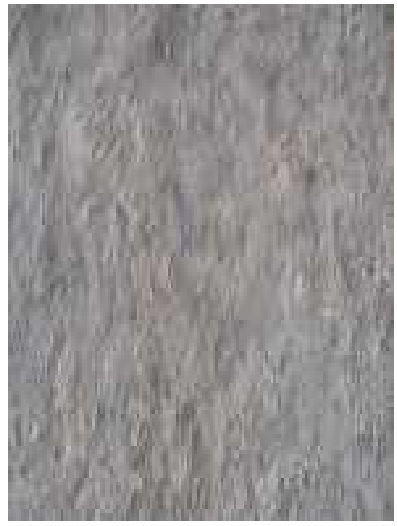

Gambar 5. Lapisan $\mathrm{TiO}_{2}$-zeolit pada permukaan keramik

Bahan keramik dipilih berdasarkan penelitian sebelumnya yang membandingkan kekuatan ikatan lapisan komposit pada tiga media yaitu aluminium, stainless steel, dan keramik. Berdasarkan penelitian tersebut diperoleh hasil bahwa lapisan komposit yang menempel pada stainless steel dan alumunium tidak merata serta mudah terkelupas.

Kelebihan menggunakan keramik adalah lebih merata, mudah dibentuk, tidak diperlukan proses preparasi seperti pada media aluminium dan stailess steel sehingga mengurangi penggunaan bahan kimia (Naimah et al. 2014). Keramik yang telah dilapisi $\mathrm{TiO}_{2}-$ karbon aktif dan $\mathrm{TiO}_{2}$-zeolit ditempatkan pada reaktor tertutup di yang berada diatas hotplate stirer yang dilengkapi lampu ultraviolet (UV) yang berfungsi sebagai sumber energi foton.

Pada saat lampu UV dinyalakan terjadi penyinaran, maka dengan adanya energi foton tersebut titanium akan menghasilkan pasangan elektron $\left(e^{-}\right)$- lubang $\left(h^{+}\right)$. Yang dapat mereduksi limbag $\mathrm{Cr}(\mathrm{VI})$. Adanya penambahan absorben berupa karbon aktif dan zeolit akan mempercepat proses reduksi limbah $\mathrm{Cr}(\mathrm{VI})$ hal ini dikarenakan kehadiran absorben berupa karbon aktif dan zeolit (Guritno 2012). Mekanisme proses fotokatalis dapat dilihat pada Gambar 6.

Hasil dari proses elektrokoagulasi yang optimal yaitu menggunakan elektroda alumunium dengan waktu proses 3 jam yang mampu menurunkan konsentrasi limbah $\mathrm{Cr}(\mathrm{VI})$ hingga mencapai $8,7 \mathrm{mg} / \mathrm{L}$.

Tahap selanjutnya mengolah limbah $\mathrm{Cr}$ (VI) dengan proses fotokatalisis. Proses fotokatalisis merupakan proses yang menggunakan cahaya (lampu UV) sebagai energi fotonnya. Hasil percobaan yang dilakukan dapat dilihat pada Gambar 7.

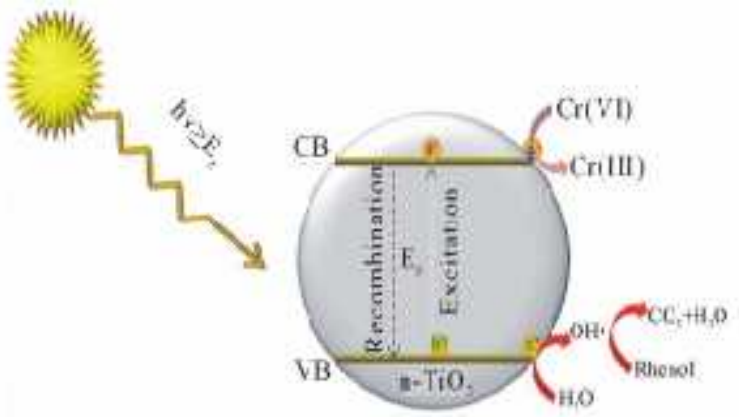

Gambar 6. Mekanisme fotokatalis dalam mereduksi limbah Cr (VI) (Shaban 2013)

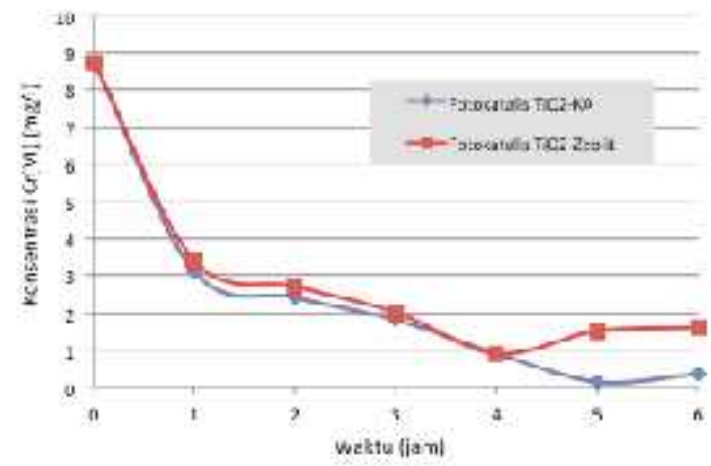

Gambar 7. Grafik reduksi Cr (VI) dengan fotokatalis

Pada fotokatalis $\mathrm{TiO}_{2}$-karbon aktif terjadi penurunan konsentrasi $\mathrm{Cr}(\mathrm{VI})$ mulai jam pertama hingga titik optimal terjadi pada jam ke-5 sebesar $0,1 \mathrm{mg} / \mathrm{L}$ atau reduksi sebesar $98,8 \%$. Akan tetapi pada jam ke-6, penurunan tidak optimal karena kemampuan degradasi fotokatalis mengalami kejenuhan proses sehingga penurunan konsentrasi tidak optimal yang disebabkan karena polutan telah banyak menempel pada permukaan komposit sehingga menutupi daerah tempat terjadinya proses fotokatalis, sedangkan Gambar 7 menjelaskan proses fotokatalis dengan komposit $\mathrm{TiO}_{2}$-zeolit.

Zeolit merupakan zat alam yang memiliki kemampuan adsorpsi. Adanya pengemban zeolit terhadap katalis $\mathrm{TiO}_{2}$ akan meningkatkan kemampuan degradasi dari fotokatalis karena adanya proses adsorpsi pada permukaan zeolit (Damayanti et al. 2014 dan Perdana 2014). Gambar 7 menunjukkan aktivitas penurunan limbah $\mathrm{Cr}(\mathrm{VI})$ dengan proses fotokatalisis.

Konsentrasi awal $\mathrm{Cr} \quad(\mathrm{VI}) \quad 8,7 \quad \mathrm{mg} / \mathrm{L}$ mengalami penurunan dengan fotokatalisis menggunakan $\mathrm{TiO}_{2}$-zeolit menjadi $0,9 \mathrm{mg} / \mathrm{L}$ atau tereduksi sebesar $89,7 \%$ selama 4 jam. Dari Gambar 7 juga tampak penurunan kinerja 
reduksi $\mathrm{Cr}(\mathrm{VI})$ dengan menggunakan $\mathrm{TiO}_{2}$-zeolit setelah 4 jam proses fotokatalisis. Hal ini terjadi karena setelah 4 jam, lapisan $\mathrm{TiO}_{2}$-zeolit sedikit terkelupas dari permukaan keramik yang kemungkinan disebabkan proses pelapisan $\mathrm{TiO}_{2}$-zeolit pada keramik yang kurang sempurna.

Hasil proses fotokatalisis menggunakan $\mathrm{TiO}_{2}$-karbon aktif lebih baik jika dibandingkan menggunakan $\mathrm{TiO}_{2}$-zeolit. Konsentrasi akhir fotokatalisis $\mathrm{TiO}_{2}$-karbon aktif dari $8,7 \mathrm{mg} / \mathrm{L}$ turun menjadi $0,1 \mathrm{mg} / \mathrm{L}$ atau tereduksi sebesar $98,8 \%$ dan telah memenuhi baku mutu limbah $\mathrm{Cr}(\mathrm{VI})$ sesuai dengan Kep-51/MENLH/10/1995 yang dipersyaratkan bagi kegiatan industri sebesar $0,1 \mathrm{mg} / \mathrm{L}$. Pada akhir proses juga tidak dihasilkan sludge yang berbahaya bagi lingkungan.

\section{KESIMPULAN}

Alumunium merupakan elektroda yang terpilih bila dibandingkan dengan elektroda besi maupun kombinasi besi dan alumunium dalam proses elektrokoagulasi karena dapat mereduksi limbah $\mathrm{Cr}(\mathrm{VI})$ paling optimal yaitu $65,2 \%$ selama 3 jam dari konsentrasi $25 \mathrm{mg} / \mathrm{L}$ menjadi $8,7 \mathrm{mg} / \mathrm{L}$. Proses reduksi dilanjutkan dengan proses fotokatalisis menggunakan $\mathrm{TiO}_{2}$-karbon aktif atau $\mathrm{TiO}_{2}$-zeolit yang ternyata proses optimal yaitu $\mathrm{TiO}_{2}$-karbon aktif dengan waktu proses selama 5 jam karena dapat mereduksi limbah $\mathrm{Cr}$ (VI) sebanyak 98,8\% menjadi 0,1 $\mathrm{mg} / \mathrm{L}$. Konsentrasi akhir ini telah memenuhi baku mutu limbah $\mathrm{Cr}$ (VI) sesuai dengan Kep-51/ MENLH/10/1995 yang dipersyaratkan bagi kegiatan industri sebesar $0,1 \mathrm{mg} / \mathrm{L}$. Pada akhir proses juga tidak dihasilkan sludge yang berbahaya bagi lingkungan.

\section{DAFTAR PUSTAKA}

Boroski,M., A.C. Rodrigues, J.C. Garcia, L.C. Sampaio, J. Nozaki, N. Hioka. 2009. Combined electrocoagulation and $\mathrm{TiO}_{2}$ photoassisted treatment applied to wastewater effluents from pharmaceutical and cosmetic industries. Journal of hazardous materials 162 (1): 448-454.

Buttler, E., Y.T. Hung, R.Y. Yeh, and M.S. Al Ahmad. 2011. Electrocoagulation in wastewater. Water 3(2): 495-525.

Damayanti, C. A., S. Wardhani, D. Purwonugroho. 2014. Pengaruh konsentrasi $\mathrm{TiO}_{2}$ dalam Zeolit terhadap degradasi methylene blue secara fotokatalitik. Kimia student journal 1 (1):8-14.

Guritno, A. 2012. Sintesis dan uji kinerja katalis komposit ag/tio ${ }_{2}$ - zeolit alam lampung - karbon aktif serta rekayasa alat untuk purifikasi udara ruang. Skripsi. Program Studi Teknik Kimia Universitas Indonesia Jakarta: Indonesia.

Harmami, I. Ulfin dan R. Setyowuryani. 2014. Penurunan kadar kromium dari limbah cair industri penyamakan kulit dengan metode elektrokoagulasi. Dalam: Prosiding seminar nasional kimia universitas negeri surabaya : 159-168.

Jati, B.N., S. Naimah, S.A. Aviandharie, dan R. Ermawati. 2012. Komposit nano $\mathrm{TiO}_{2}$ dengan PCC, zeolit atau karbon aktif untuk menurunkan total krom dan zat organik pada air limbah industri penyamakan kulit. Jurnal kimia dan kemasan 34(1): 231-236.

Kashefi, M., M. Mosthaghi, and A.H. Hasani. 2014. Efficiency evaluation of electrocoagulation process for removal of chromium (heavy metal) from municipal and industrial wastewater. Indian J. Sci. Res. (7): 1258-1268.

Kismolo, E., Nurimaniwathy, dan T. Suyatno. 2012. Karakteristik kapasitas tukar kation zeolit untuk pengolahan limbah b3 cair. Dalam: Prosiding dan presentasi ilmiah-penelitian dasar ilmu pengetahuan dan teknologi nuklir. 245251.

Naimah, S., R. Ermawati, S.A. Aviandarie, B.N. Jati, dan N.N. Aidha. 2004. Optimalisasi penggunaan absorben dan nano tio $_{2}$ dalam penerapan sebagai alat perangkap nyamuk. Laporan Penelitian. Balai Besar Kimia dan Kemasan.

Naimah, S., S.A. Aviandharie, dan R. Ermawati. 2012. Biobsorben limbah bir dan $\mathrm{tio}_{2-}$ karbon aktif, $\mathrm{tio}_{2}$ - pcc untuk penurunan limbah cair industri elektroplating. Jurnal Riset Industri 6(2): 67-75.

Perdana, N.D., S. Wardhani dan M.M. Khunur. 2014. Pengaruh penambahan hidrogen peroksida $\left(\mathrm{h}_{2} \mathrm{O}_{2}\right)$ terhadap degradasi methylene blue dengan fotokatalis znozeolit. Kimia student journal 2(2) : 567582.

Purnomo, B.H. dan M. Harsanti. 2010. Pengolahan limbah cair tekstil menggunakan proses elektrokoagulasi dengan sel Al-Al. Dalam: Prosiding 
seminar nasional teknik kimia "kejuangan" pengembangan teknologi kimia untuk pengolahan sumber daya alam Indonesia : 1-7.

Setiawati,T., I.S. Amalia, G.S. Sulistioso, dan A.A. Wisnu. 2006. Sintesa lapis tipis $\mathrm{TiO}_{2}$ dan analisis sifat fotokatalisnya. Jurnal sains materi indonesia: 141146.

Shaban, Y.A. 2013. Effective photocatalytic reduction of $\mathrm{Cr}(\mathrm{I})$ by carbon modified (CM)-n- $\mathrm{TiO}_{2}$ nanoparticles under solar irradiation. World jurnal of nano science and engineering 3:154-160.

Siringo-Ringo, E., A. Kusrijadi, dan Y. Sunarya. 2013. Penggunaan metode elektrokoagulasi pada pengolahan limbah industri penyamakan kulit menggunakan alumunium sebagai sacrificial electrode. Jurnal sains dan teknologi kimia 4(2): 96-107.

Slamet, R. Arbianti, dan Daryanto. 2005. Pengolahan limbah organik (Fenol) dan logam berat $\left(\mathrm{Cr}^{6+}\right.$ atau $\left.\mathrm{Pt}^{4+}\right)$ secara simultan dengan fotokatalis $\mathrm{TiO}_{2}, \mathrm{Zn}-\mathrm{TiO}_{2}$, dan CdS-TiO 2 . Makara teknologi 9(2) : 66-71.

Slamet, S. Bismo, R. Arbianti, dan Z. Sari. 2006. Penyisihan fenol dengan kombinasi proses adsorpsi dan fotokatalisis menggunakan karbon aktif dan $\mathrm{TiO}_{2}$. Jurnal teknologi 4 : 303-311.
Susanto, R. 2008. Optimasi koagulasi-flokulasi dan analisis kualitas air pada industri semen. Skripsi. Fakultas Sains Dan Teknologi Univeritas Islam Negeri Syarif Hidayatullah Jakarta: Indonesia.

Susetyaningsih,R., E. Kismolo, dan Prayitno. 2008. Kajian proses elektrokoagulasi untuk pengolahan limbah cair. Dalam: Prosiding seminar nasional IV SDM Teknologi Nuklir: 339-344.

Trapsilasiwi, K. R., dan A.F. Assomadhi. 2012. Aplikasi elektrokoagulasi menggunakan pasangan elektroda alumunium untuk pengolahan air dengan sistem kontinyu :1-17.

Wang, X., S.O. Pehkonen, and A.K. Ray. 2004. Removal of aqueous $\mathrm{Cr}(\mathrm{VI})$ by a combination of photocatalytic reduction and coprecipitation. Ind. Eng. Chem. Res. 43 (7): 1665-1672.

Zhang,Y., Y.Q. Cong, and Q. Wang. 2013. Electrocoagulation- $\mathrm{TiO}_{2} \quad$ Photoassisted combined system applied to methyl orange wastewater removal. Environmental engineering and management journal 12(3): 517-526.

Zongo, I., B. Merzouk, K. Palm, J. Wethe, A.H. Maiga, J.P. Leclerc, and F. LaPicque. 2012. Study of an electrocoagulation (EC) unit for the treatment of industrial effluent of Ouagadougou, Burkina Faso. Adv. Appl. Sci. Res. 3(1):572582. 